\title{
ANALISIS POTENSI EKONOMI LOKAL DAN MODEL PENGEMBANGAN PERTANIAN DI KABUPATEN MAHAKAM ULU
}

\author{
Karmini $^{1}$, Karyati ${ }^{2}$ \\ ${ }^{1}$ Jurusan/Program Studi Agribisnis, Fakultas Pertanian, Universitas Mulawarman. Kampus \\ Gunung Kelua, Jl. Pasir Balengkong, Samarinda, Kalimantan Timur, Indonesia. Email: \\ karmini.kasiman@yahoo.com. \\ ${ }^{2}$ Fakultas Kehutanan, Universitas Mulawarman. Kampus Gunung Kelua, \\ Jl. Ki Hajar Dewantara, Samarinda, Kalimantan Timur, Indonesia. \\ Email: karyati.hanapi@yahoo.com
}

\begin{abstract}
ABSTRAK
Analisis Potensi Ekonomi Lokal dan Model Pengembangan Pertanian di Kabupaten Mahakam Ulu. Kabupaten Mahakam Ulu memiliki sumberdaya yang sebagian telah dikelola oleh masyarakat menjadi kegiatan ekonomi yang potensial. Penelitian ini bertujuan untuk mengidentifikasi, menganalisis, dan melakukan assessment serta melukiskan model pengembangan pertanian di Kabupaten Mahakam Ulu. Statistika deskriptif digunakan untuk menganalisis data penelitian. Kabupaten Mahakam Ulu memiliki potensi ekonomi yang terdapat pada berbagai lapangan usaha. Terdapat peluang untuk mengembangkan potensi ekonomi lokal di wilayah tersebut. Potensi sumberdaya alam, sumberdaya manusia, dan sumberdaya fisik mendukung pengembangan kegiatan ekonomi pada tingkat lokal di Kabupaten Mahakam Ulu. Peengembangan pertanian dapat dilakukan dengan program/kegiatan yang sesuai dengan potensi ekonomi lokal. Model pengembangan pertanian menunjukkan pembangunan pertanian dipengaruhi dan didukung oleh pembangunan pada lapangan usaha lainnya.
\end{abstract}

Kata kunci: Ekonomi lokal, Mahakam Ulu, model, pertanian, potensi.

\begin{abstract}
Analysis of Local Economic Potential and Agricultural Development Model in Regency of Mahakam Ulu. Regency of Mahakam Ulu has resources which a part of them has managed by people become potential economic activities. The aims of this research were to identify, analysis, and assess, also to delineate a model of agricultural development in Regency of Mahakam Ulu. Descriptive statistics was used to analyze the research data. Regency of Mahakam Ulu has economic potential in some business fields. There are opportunities to develop the local economic potential in that area. The potential of natural, human, and physical resources support the development of economic activities at local level in Regency of Mahakam Ulu. Agriculture development could be done with programs/activities related to local economic potential. The agriculture development model shows agriculture development is influenced and supported by development in others business field.
\end{abstract}

Key words: Local economic, Mahakam Ulu, model, agriculture, potential.

\section{PENDAHULUAN}

Pertumbuhan ekonomi suatu daerah merupakan fungsi dari pemanfaatan potensi sumberdaya alam, sumberdaya manusia, dan sumberdaya fisik yang dimiliki daerah tersebut. Pengertian potensi menurut Balai Pustaka (2005) adalah kemampuan yang mempunyai kemungkinan untuk dikembangkan. Sandy (1985) dalam Sitanala, dkk. (1988) menyatakan sumberdaya adalah segala sesuatu, baik berupa benda nyata ataupun 
bukan benda nyata yang dibutuhkan oleh manusia untuk kelangsungan hidupnya.

Jika ditinjau dari segi ekonomi sumberdaya, Mouzon (1966) seperti dikutip Sitanala, dkk. (1988) menyatakan terdapat tiga unsur sumberdaya yang penting, yaitu tanah, tenaga kerja, dan modal. Perkembangan selanjutnya menunjukkan peranan tanah secara ekonomis bukan saja terbatas pada produk-produk pertanian yang menghasilkan bahan mentah, akan tetapi sudah berfungsi pula sebagai sumberdaya ruang (spatial resources), sumberdaya energi, dan sumberdaya bahan dasar (material resources). Haeruman (1987) dalam Sitanala, dkk. (1988) memberikan konsep mengenai sumberdaya alam sebagai suatu sumberdaya yang terbentuk karena kekuatan alamiah, misalnya tanah, air dan perairan, biotis, udara dan ruang, mineral, bentang alam (landscape), panas bumi dan gas bumi, angin, dan pasang surut/arus laut. Selain sumberdaya alam, di dalam kelompok sumberdaya tersebut terdapat sumberdaya-sumberdaya lainnya, seperti budaya dan alam-budaya. Kekayaan sumberdaya alam yang melimpah antara lain terdapat di Kabupaten Mahakam Ulu yang menurut Badan Pusat Statistik Kabupaten Mahulu (BPS Mahulu) (2018) memiliki wilayah darat seluas $15.315 \mathrm{~km}^{2}$.

Selain sumberdaya alam, Kabupaten Mahulu juga memiliki sumberdaya manusia. Jumlah penduduk di Kabupaten Mahakam Ulu pada tahun 2017 (BPS Mahulu, 2018) sebanyak 33.420 orang terdiri dari 17.737 laki-laki dan 15.683 perempuan dengan rasio jenis kelamin 1,13. Domisili penduduk Kabupaten Mahakam Ulu tersebar di 5 kecamatan yang mencakup 50 kampung. Keberadaan sumberdaya manusia memegang peranan sebagai pemilik sumberdaya dan juga sebagai pelaku proses produksi. Keberadaan tenaga kerja yang produktif tentunya akan mempercepat laju pertumbuhan ekonomi.

Berbeda dengan sumberdaya alam, maka sumberdaya modal dapat dibuat manusia. Sumberdaya modal yang dimaksud di sini adalah seluruh modal ekonomi yang diperlukan dalam rangka memproduksi suatu barang. Lingkungan ekonomi menggolongkan berbagai macam modal baik selaku barang modal maupun sebagai barang investasi. Pengadaan modal tersebut dikenal sebagai akumulasi modal. Meningkatnya akumulasi modal akan berpengaruh kepada peningkatan proses produksi yang pada akhirnya akan berakibat terhadap meningkatnya pendapatan nasional. Kabupaten Mahakam Ulu menghasilkan Produk Domestik Regional Bruto (PDRB) atas dasar harga berlaku tahun 2017 sebesar Rp2.336.400,7 juta, di mana meningkat jika dibandingkan dengan tahun 2015 yang hanya sebesar Rp1.980.622,5 juta (BPS Mahulu, 2018).

Potensi sumberdaya yang dimiliki suatu daerah dapat berubah menjadi potensi ekonomi jika sumberdaya yang ada dapat dimanfaatkan secara optimal dalam kegiatan produksi pertanian. Semakin tinggi potensi ekonomi yang dimiliki suatu daerah menunjukkan semakin besar tingkat pemanfaatan sumberdaya dan semakin tinggi kemajuan ekonomi daerah. Identifikasi dan analisis dilakukan untuk mengetahui potensi ekonomi yang dimiliki masyarakat hingga tingkat lokal. Kegiatan tersebut juga dimaksudkan untuk mengetahui kendala dan peluang yang dihadapi masyarakat lokal dalam mengembangkan dan memanfaatkan potensi ekonomi. Assessment potensi ekonomi tingkat lokal menjadi suatu kebutuhan untuk mengetahui kemampuan masyarakat lokal dalam menyelenggarakan kegiatan ekonomi. Pemahaman tentang konsep tersebut dapat menjadi basis dalam pembentukan model pembangunan 
wilayah khususnya model pengembangan pertanian.

Tujuan penelitian ini adalah untuk melakukan identifikasi, analisis, dan assessment potensi ekonomi lokal serta melukiskan model pengembangan pertanian di Kabupaten Mahakam Ulu. Penelitian ini memberikan informasi tentang potensi ekonomi lokal dan menghasilkan model pengembangan pertanian sebagai bahan pertimbangan bagi masyarakat, pemerintah, dan pihakpihak lain yang terkait dalam pengelolaan sumberdaya dan penyusunan rencana tata ruang wilayah Kabupaten Mahakam Ulu yang selaras dengan kepentingan, kebutuhan, dan kondisi lokal. Kebijakankebijakan pembangunan pada dasarnya bertujuan untuk meningkatkan kesejahteraan masyarakat (Karmini, 2015).

Kerangka pemikiran kegiatan penelitian ini diawali dengan kegiatan identifikasi potensi ekonomi dan dilanjutkan dengan melakukan analisis dan assessment. Analisis potensi ekonomi lokal akan menghasilkan rumusan kendala dan peluang pengembangan usaha. Hasil kegiatan assessment berupa klasifikasi apakah lapangan usaha kurang potensial, potensial, atau sangat potensial untuk dikembangkan di Kabupaten Mahakam Ulu. Hasil identifikasi, analisis, dan assessment menjadi dasar dalam penyusunan model pengembangan pertanian (Gambar 1).

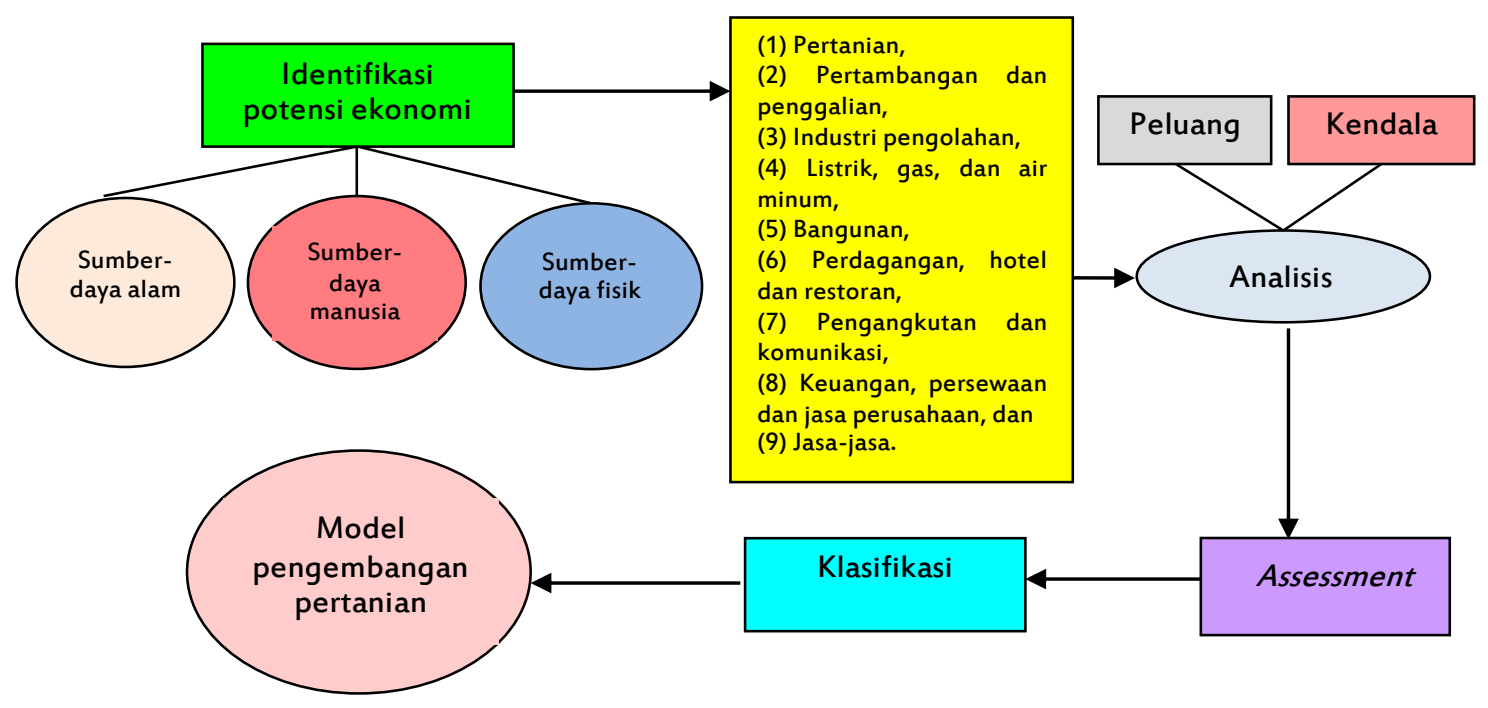

Gambar 1. Kerangka Pemikiran.

\section{METODA PENELITIAN}

\subsection{Tempat dan Waktu}

Penelitian dilaksanakan di Kabupaten Mahakam Ulu, Propinsi Kalimantan Timur, Indonesia sejak Juli hingga Desember 2019. Lokasi penelitian ditentukan dengan cara (Gambar 2) sebagai berikut:

1. Kabupaten Mahakam Ulu terdiri 5 kecamatan yaitu Kecamatan Laham (5 kampung), Long Hubung kampung), Long Bagun (11 kampung), Long Pahangai (13 kampung), dan Long Apari (10 kampung).

2. Kemudian ditentukan 2 kecamatan secara purposive yaitu Kecamatan Long Bagun dan Long Apari.

3. Selanjutnya lokasi penelitian dipilih secara acak masing-masing 2 kampung di 2 kecamatan tersebut. Penelitian dilaksanakan di Kampung Ujoh Bilang dan Kampung Batoq Kelo di Kecamatan Long Bagun. Sementara itu 
lokasi penelitian di Kecamatan Long Penaneh dan Kampung Long Kerioq. Apari berada di Kampung Long

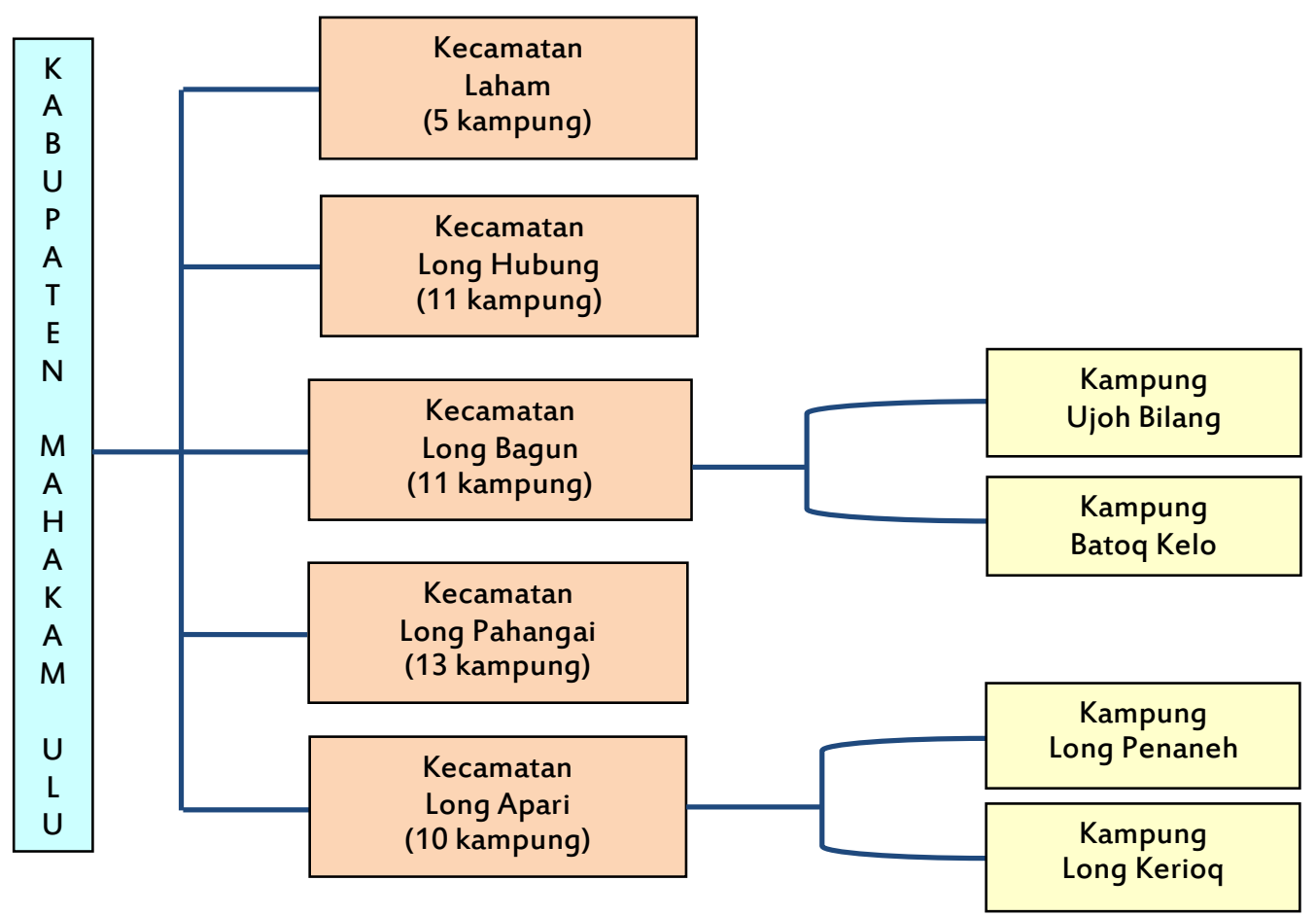

Gambar 2. Tahapan Penentuan Lokasi Penelitian.

\subsection{Metode Pengumpulan Data}

Penelitian ini mengumpulkan data primer dan sekunder. Data primer adalah data yang sesuai dengan lingkup substansi materi studi yang diperoleh dari investigasi/pengamatan di lapangan dan wawancara mendalam (in depth interview) terhadap responden di masing-masing lokasi penelitian. Data sekunder dikumpulkan dari instansi terkait seperti BPS Mahulu.

\subsection{Metode Pengambilan Sampel}

Metode purposive sampling digunakan dalam penelitian ini. Pada masing-masing kampung yang terpilih tersebut dipilih sampel pelaku usaha pada berbagai lapangan usaha. International Standard Industrial Classification of All Economic Activities (ISIC) yang ditetapkan Perserikatan Bangsa-bangsa (Karmini, 2016b) membagi jenis lapangan usaha meliputi bidang (1) pertanian, (2) pertambangan dan penggalian, (3) industri pengolahan, (4) listrik, gas dan air minum, (5) bangunan, (6) perdagangan, hotel dan restoran, (7) pengangkutan dan komunikasi, (8) keuangan, persewaan dan jasa perusahaan, dan (9) jasa-jasa. Jumlah sampel dalam penelitian ini adalah 36 responden.

\subsection{Metode Analisis Data}

Data yang dikumpulkan dari lapangan akan diolah sebelum dianalisis. Pengolahan data dilakukan dengan kompilasi data yaitu proses seleksi terhadap data dan informasi yang diperoleh selanjutnya data dikelompokkan sesuai dengan kebutuhan analisis yang akan dilakukan. Jika tahap kompilasi telah dilakukan, tahapan selanjutnya adalah analisis data dan interpretasi.

Metode analisis data yang digunakan dalam penelitian ini adalah: 
1. Identifikasi potensi ekonomi dilakukan dengan menggunakan metode analisis data secara deskriptif berupa perhitungan jumlah.

2. Analisis potensi ekonomi lokal menggunakan analisis data secara deskriptif.

3. Assessment potensi ekonomi lokal. Analisis data meliputi:

a) Penentuan kontribusi atas unsurunsur yang mempengaruhi potensi ekonomi lokal. Perhitungan dilakukan dengan membandingkan antara skor Nilai Kenyataan (NK)

$$
\mathrm{KP}=\frac{\mathrm{NHTT}-\mathrm{NHTR}}{\mathrm{JS}}
$$

\section{Total NHTT - Total NHTR}

$$
\mathrm{KP}=\frac{\mathrm{JS}}{\mathrm{J}}
$$

dari hasil penelitian dengan skor Nilai Harapan Tertinggi (NHTT) dikali dengan $100 \%$. Jika skor kenyataan semakin mendekati skor harapan tertinggi, maka kontribusi masing-masing unsur dalam membentuk potensi ekonomi semakin tinggi.

b) Rumus penentuan kriteria penilaian masing-masing unsur yang mempengaruhi potensi ekonomi dihitung berdasarkan interval penilaian masing-masing unsur:

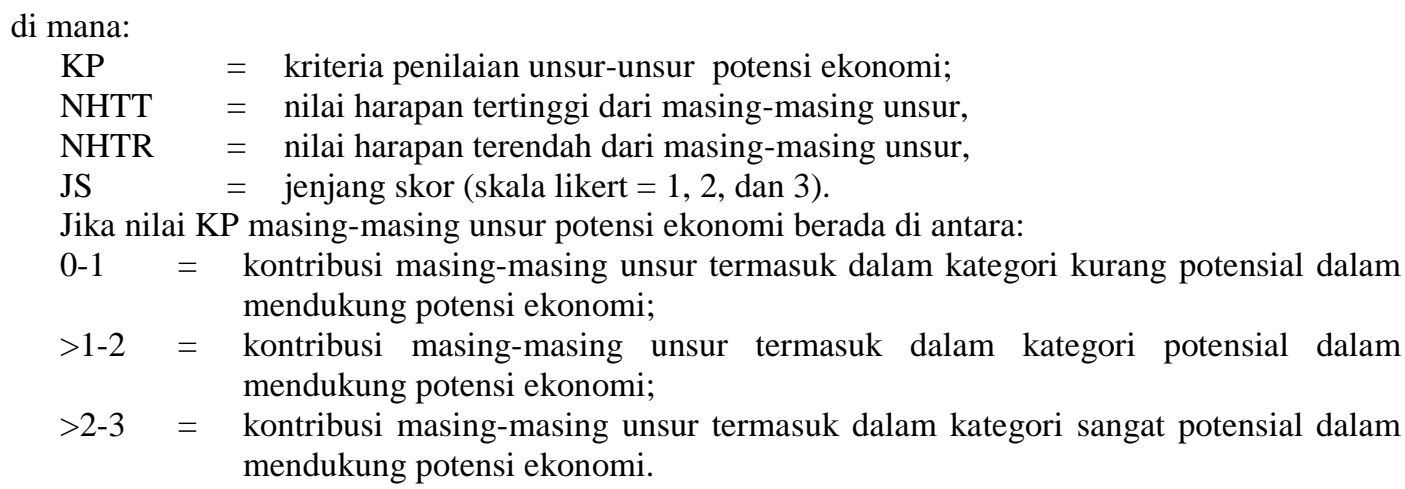

4. Penetapan model pengembangan pertanian dilakukan dengan menggunakan analisis data secara deskriptif.

\section{HASIL PENELITIAN DAN PEMBAHASAN}

\subsection{Potensi Ekonomi di Kabupaten} Mahakam Ulu

Kegiatan usaha yang berkembang di Kabupaten Mahakam Ulu bergerak pada berbagai lapangan usaha. Data pada Tabel 1 menunjukkan terdapat potensi ekonomi pada lapangan usaha di bidang pertanian, perdagangan, hotel, dan restoran, keuangan, persewaan, dan jasa perusahaan serta jasa-jasa. Jumlah kegiatan ekonomi yang berkembang di masyarakat masih terbatas jumlahnya. Kegiatan perdagangan yang dilakukan usaha kecil telah berkembang di seluruh kecamatan, demikian halnya dengan usaha restoran atau rumah makan. Hotel atau penginapan telah berdiri di seluruh kecamatan kecuali Kecamatan Laham. Fasilitas kesehatan berupa Puskesmas dan Puskesmas Pembantu telah tersedia di seluruh kecamatan disertai tenaga kesehatan yang bertugas di daerah tersebut. Fasilitas 
pendidikan telah tersedia dari Kelompok Bermain, Taman Kanak-Kanak, Sekolah Dasar hingga Sekolah Menengah Pertama dan telah dapat dinikmati masyarakat.
Berbagai jenis kegiatan di sektor keuangan, persewaan, dan jasa perusahaan dapat dilihat di hasil penelitian terdahulu (Karmini, 2016c).

Tabel 1. Potensi Sumberdaya Pada Beberapa Lapangan Usaha di Kabupaten Mahakam Ulu.

\begin{tabular}{|c|c|c|c|c|c|c|c|}
\hline \multirow[t]{2}{*}{ No. } & \multirow[t]{2}{*}{ Lapangan usaha } & \multirow[t]{2}{*}{ Potensi ekonomi } & \multicolumn{5}{|c|}{ Kecamatan } \\
\hline & & & Laham & $\begin{array}{c}\text { Long } \\
\text { Hubung }\end{array}$ & $\begin{array}{c}\text { Long } \\
\text { Bagun }\end{array}$ & $\begin{array}{c}\text { Long } \\
\text { Pahangai }\end{array}$ & $\begin{array}{l}\text { Long } \\
\text { Apari }\end{array}$ \\
\hline 1 & Pertanian & Petsai (ha) & 3 & 2 & 2 & 5 & 4 \\
\hline \multirow[t]{5}{*}{2} & Perdagangan, Hotel, dan & Pedagang besar (orang) & 2 & 7 & 3 & & \\
\hline & Restoran & Pedagang menengah (orang) & 3 & & 10 & 3 & \\
\hline & & Pedagang kecil (orang) & 28 & 119 & 70 & 51 & 63 \\
\hline & & Hotel/penginapan (buah) & & 6 & 6 & 2 & 2 \\
\hline & & Restoran (buah) & 1 & 8 & 30 & 1 & 8 \\
\hline 3 & $\begin{array}{l}\text { Keuangan, Persewaan dan } \\
\text { Jasa Perusahaan }\end{array}$ & Koperasi (buah) & 7 & 11 & 10 & 8 & 9 \\
\hline \multirow[t]{21}{*}{4} & Jasa-jasa & Puskesmas (buah) & 1 & 1 & 1 & 1 & 1 \\
\hline & & Puskesmas Pembantu (buah) & 6 & 10 & 13 & 14 & 10 \\
\hline & & Tenaga keperawatan (orang) & 16 & 28 & 46 & 30 & 28 \\
\hline & & Tenaga kebidanan (orang) & 13 & 9 & 27 & 15 & 12 \\
\hline & & Tenaga kefarmasian (orang) & 1 & & 7 & 3 & 2 \\
\hline & & Kelompok Bermain & & & & & \\
\hline & & - Sekolah (buah) & 3 & 9 & 10 & 6 & 3 \\
\hline & & - Murid (orang) & 55 & 362 & 423 & 125 & 152 \\
\hline & & - Guru (orang) & 12 & 67 & 54 & 18 & 22 \\
\hline & & Taman Kanak-kanak & & & & & \\
\hline & & - Sekolah (buah) & & 8 & 7 & 6 & \\
\hline & & - Murid (orang) & & 236 & 188 & 125 & \\
\hline & & - Guru (orang) & & 51 & 25 & 28 & 23 \\
\hline & & Sekolah Dasar & & & & & \\
\hline & & - Sekolah (buah) & 5 & 9 & 12 & 8 & 5 \\
\hline & & - Murid (orang) & 414 & 1.033 & 1.585 & 652 & 624 \\
\hline & & - Guru (orang) & 57 & 126 & 150 & 100 & 65 \\
\hline & & Sekolah Menengah Pertama & & & & & \\
\hline & & - Sekolah (buah) & 2 & 5 & 5 & 2 & 1 \\
\hline & & - Murid (orang) & 142 & 474 & 275 & 246 & 248 \\
\hline & & - Guru (orang) & 6 & 19 & 28 & 10 & 7 \\
\hline
\end{tabular}

Sumber: Badan Pusat Statistik Kabupaten Mahakam Ulu (2018).

3.2. Potensi Ekonomi Tingkat Lokal di Kabupaten Mahakam Ulu

Hasil wawancara dengan responden menunjukkan kegiatan ekonomi yang telah berkembang hingga tingkat lokal di Kabupaten Mahakam Ulu meliputi lapangan usaha pertanian, industri pengolahan, perdagangan, hotel, dan restoran. Pada lapangan usaha keuangan, persewaan, dan jasa perusahaan, diketahui hanya koperasi yang berkembang di lokasi penelitian. Selain itu pemerintah telah menyediakan pelayanan di bidang jasa khususnya bidang pendidikan dan kesehatan. Namun pelayanan umum lainnya seperti listrik, gas, dan air bersih serta pengangkutan dan komunikasi masih sangat minim keberadaannya. Masyarakat sangat membutuhkan pembangunan khususnya pada lapangan usaha lain yang belum banyak berkembang. Jenis usaha, kendala, dan peluang pengembangan usaha pada setiap lapangan usaha di lokasi penelitian dapat dilihat pada Tabel 2. 


\subsection{Assessement Potensi Ekonomi Lokal di Kabupaten Mahakam Ulu \\ Hasil penelitian menunjukkan} kegiatan ekonomi pada lapangan usaha pertanian potensial untuk dikembangkan pada tingkat lokal di Kabupaten Mahakam Ulu karena didukung sekitar $77 \%$ potensi sumberdaya alam, sumberdaya manusia, dan sumberdaya fisik. Sementara $23 \%$ potensi sumberdaya lainnya perlu dimanfaatkan secara lebih intensif. Hasil yang sama juga ditemukan pada lapangan usaha bidang perdagangan, hotel, dan restoran. Lapangan usaha jasa-jasa belum berkembang luas namun potensial untuk dikembangkan di kabupaten tersebut karena didukung sekitar $64 \%$ potensi sumberdaya sedangkan sekitar $36 \%$ potensi sumberdaya yang lainnya perlu dikelola lebih lanjut. Secara keseluruhan, sekitar $73 \%$ potensi sumberdaya alam, sumberdaya manusia, dan sumberdaya fisik mendukung pengembangan kegiatan ekonomi pada tingkat lokal di Kabupaten Mahakam Ulu dan masih terdapat sekitar $27 \%$ potensi sumberdaya yang perlu dikelola secara maksimal.

Pengembangan kegiatan ekonomi memerlukan investasi. Semakin besar investasi yang dilakukan oleh berbagai pihak diharapkan akan semakin besar peluang untuk mengembangkan kegiatan ekonomi. Investasi yang dilakukan pada berbagai lapangan usaha dipengaruhi oleh berbagai faktor. Faktor-faktor yang mempengaruhi investasi pada sektor non tambang antara lain potensi sumberdaya alam, potensi sumberdaya manusia, karakteristik wilayah (potensi sumber daya fisik), dan iklim investasi (Karmini, 2016d). Program, kegiatan, dan strategi peningkatan investasi non tambang dapat dilihat pada hasil penelitian terdahulu (Karmini, 2019).

\subsection{Model Pengembangan Pertanian di Kabupaten Mahakam Ulu}

Model pengembangan pertanian di Kabupaten Mahakam Ulu (Gambar 3) menyajikan beberapa program/kegiatan utama yang dapat dilakukan untuk mengembangkan pertanian serta lapangan usaha yang lain. Program/kegiatan lain dapat dilakukan untuk menunjang keberhasilan pelaksanaan program/kegiatan utama tersebut. Beberapa program dan kegiatan pokok yang dapat meningkatkan produksi, laju pertumbuhan pendapatan daerah, dan investasi pada sektor pertanian, pertanian tanaman pangan, hortikultura, peternakan, kehutanan, dan perikanan dapat dilihat pada hasil penelitian terdahulu (Karmini, 2014a, 2014b, 2016a, 2019; Purnomo, 2014).

Beberapa pihak sangat berperan dalam mendukung pengembangan pertanian, sedangkan pihak lain yang tidak tertampilkan dalam model dapat berkontribusi nyata juga dalam pelaksanaan program/kegiatan tersebut. Pengembangan pertanian dapat dilaksanakan dengan program/kegiatan yang sesuai dengan potensi ekonomi lokal. Keberhasilan kegiatan pengembangan pertanian didukung oleh pelaksanaan pembangunan pada lapangan usaha yang lain. Model pengembangan pertanian di Kabupaten Mahakam Ulu yang dihasilkan dari penelitian ini berbeda dengan model pengembangan potensi ekonomi lokal di wilayah pembangunan dataran rendah Kabupaten Kutai Barat (Karmini, 2021). Namun keduanya menunjukkan bahwa upaya pengembangan sektor pertanian, kehutanan, dan perikanan seharusnya dilakukan dengan mengintegrasikan program kerja yang akan dirumuskan pada suatu wilayah tertentu (Karmini, 2018). Hal tersebut disebabkan, pertumbuhan ekonomi hampir selalu disertai dengan transformasi ekonomi dari pertanian ke kegiatan lain (Northon, dkk., 2010). Pertumbuhan pertanian yang 
cepat memiliki dampak dominan pada pertumbuhan lapangan kerja pada sektor

non pertanian di pedesaan (Mellor, 2017).

Tabel 2. Potensi Ekonomi Tingkat Lokal di Lokasi Penelitian.

\begin{tabular}{|c|c|c|c|c|c|}
\hline No. & $\begin{array}{c}\text { Lapangan } \\
\text { usaha }\end{array}$ & $\begin{array}{c}\text { Bidang kegiatan } \\
\text { responden }\end{array}$ & Kendala & Kegiatan & Peluang \\
\hline 1 & Pertanian & $\begin{array}{l}\text { Usaha pertanian di } \\
\text { Kampung } \\
\text { Penaneh dan } \\
\text { Kerioq. } \\
\text { Usahatani } \\
\text { ladang, karet, kopi, } \\
\text { dan kelapa. } \\
\text { Budidaya dan } \\
\text { penangkapan ikan di } \\
\text { sungai. } \\
\text { Usaha peternakan } \\
\text { sapi, kambing, babi, } \\
\text { ayam buras, ayam } \\
\text { potong, dan itik. }\end{array}$ & 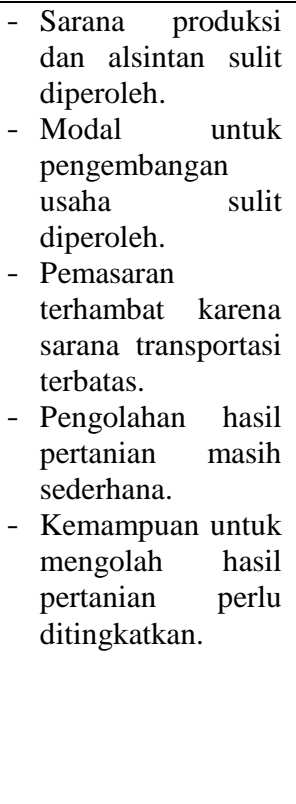 & $\begin{array}{l}\text { - Penyediaan dan } \\
\text { penyaluran sarana } \\
\text { produksi, alat, dan } \\
\text { mesin pertanian. } \\
\text { - Penyediaan dan } \\
\text { penyaluran modal } \\
\text { usaha. } \\
\text { - Pembangunan } \\
\text { sarana transportasi } \\
\text { umum. } \\
\text { - Pengembangan } \\
\text { industri } \\
\text { pengolahan hasil } \\
\text { pertanian. } \\
\text { - Peningkatan } \\
\text { kualitas } \\
\text { sumberdaya } \\
\text { manusia. } \\
\text { - Pengembangan } \\
\text { usaha pemanfaatan } \\
\text { hasil hutan non } \\
\text { kayu. }\end{array}$ & $\begin{array}{l}\text { Pengembangan } \\
\text { berbagai usaha } \\
\text { peternakan khususnya } \\
\text { budidaya burung walet } \\
\text { di di Kampung Long } \\
\text { Penaneh dan Long } \\
\text { Kerioq. }\end{array}$ \\
\hline 2 & $\begin{array}{l}\text { Pertambangan } \\
\text { dan } \\
\text { Penggalian }\end{array}$ & & Wilayah konservasi. & $\begin{array}{l}\text { Pemeliharaan } \\
\text { kawasan hutan untuk } \\
\text { konservasi. }\end{array}$ & \\
\hline 3 & $\begin{array}{l}\text { Industri } \\
\text { Pengolahan }\end{array}$ & $\begin{array}{l}\text { Salon dan meubel. } \\
\text { Usaha kerajinan } \\
\text { kulit, anyaman, dan } \\
\text { gerabah di Kampung } \\
\text { Ujoh Bilang. }\end{array}$ & $\begin{array}{l}\text { - Kualitas } \\
\text { sumberdaya } \\
\text { manusia perlu } \\
\text { ditingkatkan. } \\
\text { - Pemasaran masih } \\
\text { terbatas. }\end{array}$ & $\begin{array}{l}\text { - Pengembangan } \\
\text { industri mikro, } \\
\text { kecil, menengah, } \\
\text { dan besar. } \\
\text { - Perluasan wilayah } \\
\text { pemasaran dan } \\
\text { peningkatan } \\
\text { kegiatan } \\
\text { pemasaran hasil } \\
\text { industri } \\
\text { masyarakat lokal. }\end{array}$ & $\begin{array}{l}\text { - Pengembangan } \\
\text { industri pengolahan } \\
\text { hasil pertanian, } \\
\text { perkebunan, dan } \\
\text { peternakan seperti } \\
\text { penggilingan padi, } \\
\text { pengolahan beras } \\
\text { dan produk } \\
\text { turunannya seperti } \\
\text { tepung beras, } \\
\text { industri pengolahan } \\
\text { lump, dan industri } \\
\text { pengolahan hasil } \\
\text { peternakan. } \\
\text { - Pengembangan } \\
\text { industri pengolahan } \\
\text { hasil hutan non kayu } \\
\text { misalnya kerajinan } \\
\text { tangan. }\end{array}$ \\
\hline
\end{tabular}


Tabel 2. Lanjutan.

\begin{tabular}{|c|c|c|c|c|c|c|}
\hline No. & $\begin{array}{c}\text { Lapangan } \\
\text { usaha }\end{array}$ & \multicolumn{2}{|c|}{$\begin{array}{l}\text { Bidang kegiatan } \\
\text { responden }\end{array}$} & Kendala & Kegiatan & Peluang \\
\hline 4 & $\begin{array}{l}\text { Listrik, } \\
\text { Gas, dan } \\
\text { Air Bersih }\end{array}$ & & & $\begin{array}{l}\text { - Belum mendapat } \\
\text { pelayanan listrik, gas, } \\
\text { dan air bersih. } \\
\text { - Jarak yang jauh dari } \\
\text { ibukota kabupaten. }\end{array}$ & $\begin{array}{l}\text { Pembangunan instalasi } \\
\text { listrik, gas, dan air } \\
\text { bersih. }\end{array}$ & $\begin{array}{l}\text { Pembangunan fasilitas } \\
\text { pelayanan dan } \\
\text { penyaluran listrik, gas, } \\
\text { dan air bersih bagi } \\
\text { warga masyarakat. }\end{array}$ \\
\hline 5 & Bangunan & & & $\begin{array}{l}\text { Fasilitas umum masih } \\
\text { terbatas. }\end{array}$ & $\begin{array}{l}\text { Peningkatan kuantitas } \\
\text { dan kualitas fasilitas } \\
\text { umum. }\end{array}$ & $\begin{array}{l}\text { Pembangunan dan } \\
\text { pemeliharaan fasilitas } \\
\text { umum. }\end{array}$ \\
\hline 6 & $\begin{array}{l}\text { Perdaganga } \\
\mathrm{n}, \text { Hotel, } \\
\text { dan } \\
\text { Restoran }\end{array}$ & $\begin{array}{l}\text { Toko/warung } \\
\text { Kampung } \\
\text { Penaneh dan } \\
\text { Kerioq. }\end{array}$ & $\begin{array}{r}\text { di } \\
\text { Long } \\
\text { Long }\end{array}$ & 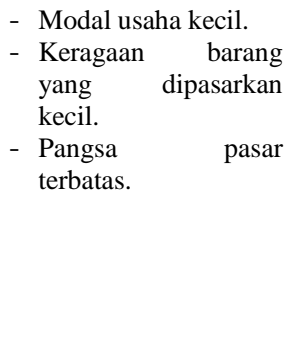 & $\begin{array}{l}\text { - Penyediaan kredit } \\
\text { usaha. } \\
\text { - Perluasan pasar dan } \\
\text { peningkatan kegiatan } \\
\text { pemasaran. }\end{array}$ & $\begin{array}{l}\text { - Pemasaran hasil } \\
\text { pertanian. } \\
\text { - Pemasaran industri } \\
\text { kerajinan khususnya } \\
\text { hasil hutan non } \\
\text { kayu khususnya } \\
\text { dari Kampung Ujoh } \\
\text { Bilang. } \\
\text { - Perluasan wilayah } \\
\text { pemasaran sarang } \\
\text { burung walet. }\end{array}$ \\
\hline 7 & $\begin{array}{l}\text { Pengangkut } \\
\text { an dan } \\
\text { Komunikasi }\end{array}$ & & & $\begin{array}{l}\text { - Lalu lintas barang } \\
\text { dan penumpang } \\
\text { masih belum ramai. } \\
\text { - Biaya transportasi } \\
\text { untuk pembelian } \\
\text { barang yang akan } \\
\text { diperdagangkan } \\
\text { sangat besar karena } \\
\text { sarana dan prasarana } \\
\text { transportasi terbatas. } \\
\text { - Fasilitas umum } \\
\text { bidang komunikasi } \\
\text { terbatas } \\
\text { jangkauannya. }\end{array}$ & $\begin{array}{l}\text { - Pembangunan } \\
\text { prasarana dan sarana } \\
\text { transportasi sungai, } \\
\text { darat, dan udara. } \\
\text { - Pembangunan } \\
\text { fasilitas umum dan } \\
\text { jaringan komunikasi. }\end{array}$ & $\begin{array}{ll}\text { - Usaha transportasi } \\
\text { sungai, darat, dan } \\
\text { udara. } & \\
\text { - Pembangunan } & \\
\text { sarana } & \text { dan } \\
\text { prasarana } & \\
\text { transportasi } & \text { seperti } \\
\text { dermaga di } & \text { Long } \\
\text { Bagun dan } & \text { di } \\
\text { daerah lain. } & \\
\text { - Pembangunan } & \\
\text { sarana } & \text { dan } \\
\text { prasarana } & \\
\text { komunikasi. } & \end{array}$ \\
\hline 8 & $\begin{array}{l}\text { Keuangan, } \\
\text { Persewaan, } \\
\text { dan Jasa } \\
\text { Perusahaan }\end{array}$ & Koperasi & & $\begin{array}{l}\text { - Lembaga keuangan } \\
\text { belum berkembang } \\
\text { di pelosok. } \\
\text { - Kegiatan usaha } \\
\text { koperasi terbatas. } \\
\text { - Kemampuan } \\
\text { wirausaha pengelola } \\
\text { perlu ditingkatkan. }\end{array}$ & $\begin{array}{l}\text { - Pembentukan } \\
\text { koperasi dan } \\
\text { lembaga keuangan } \\
\text { mikro tingkat lokal. } \\
\text { - Pembinaan dan } \\
\text { pelatihan wirausaha } \\
\text { bagi pengelola } \\
\text { koperasi. }\end{array}$ & $\begin{array}{l}\text { Pendirian koperasi } \\
\text { dan lembaga keuangan } \\
\text { lainnya khususnya di } \\
\text { Kampung Batoq Kelo } \\
\text { dan kampung lainnya. }\end{array}$ \\
\hline 9 & Jasa-jasa & $\begin{array}{l}\text { Fasilitas pendid } \\
\text { Kampung Ujoh } \\
\text { terdapat Sekolal } \\
\text { di Kampung } \\
\text { Penaneh, dan } \\
\text { fasilitas kesehata }\end{array}$ & $\begin{array}{l}\text { Can di } \\
\text { Dalang, } \\
\text { Longar } \\
\text { Longat } \\
\text { rdapat }\end{array}$ & 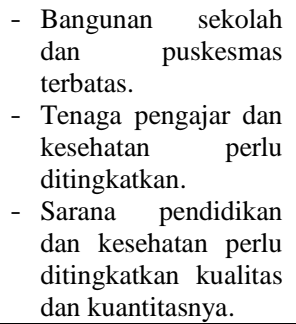 & $\begin{array}{l}\text { Pembangunan, } \\
\text { pemeliharaan, dan } \\
\text { pengembangan sarana } \\
\text { dan prasarana di bidang } \\
\text { pendidikan dan } \\
\text { kesehatan. }\end{array}$ & $\begin{array}{l}\text { - Pembangunan } \\
\text { Sekolah Dasar di } \\
\text { Kampung Kerioq } \\
\text { dan Batoq Kelo. } \\
\text { - Pembangunan r } \\
\text { Sekolah Menengah } \\
\text { Pertama di } \\
\text { Kampung Long } \\
\text { Penaneh dan Ujoh } \\
\text { Bilang. }\end{array}$ \\
\hline
\end{tabular}




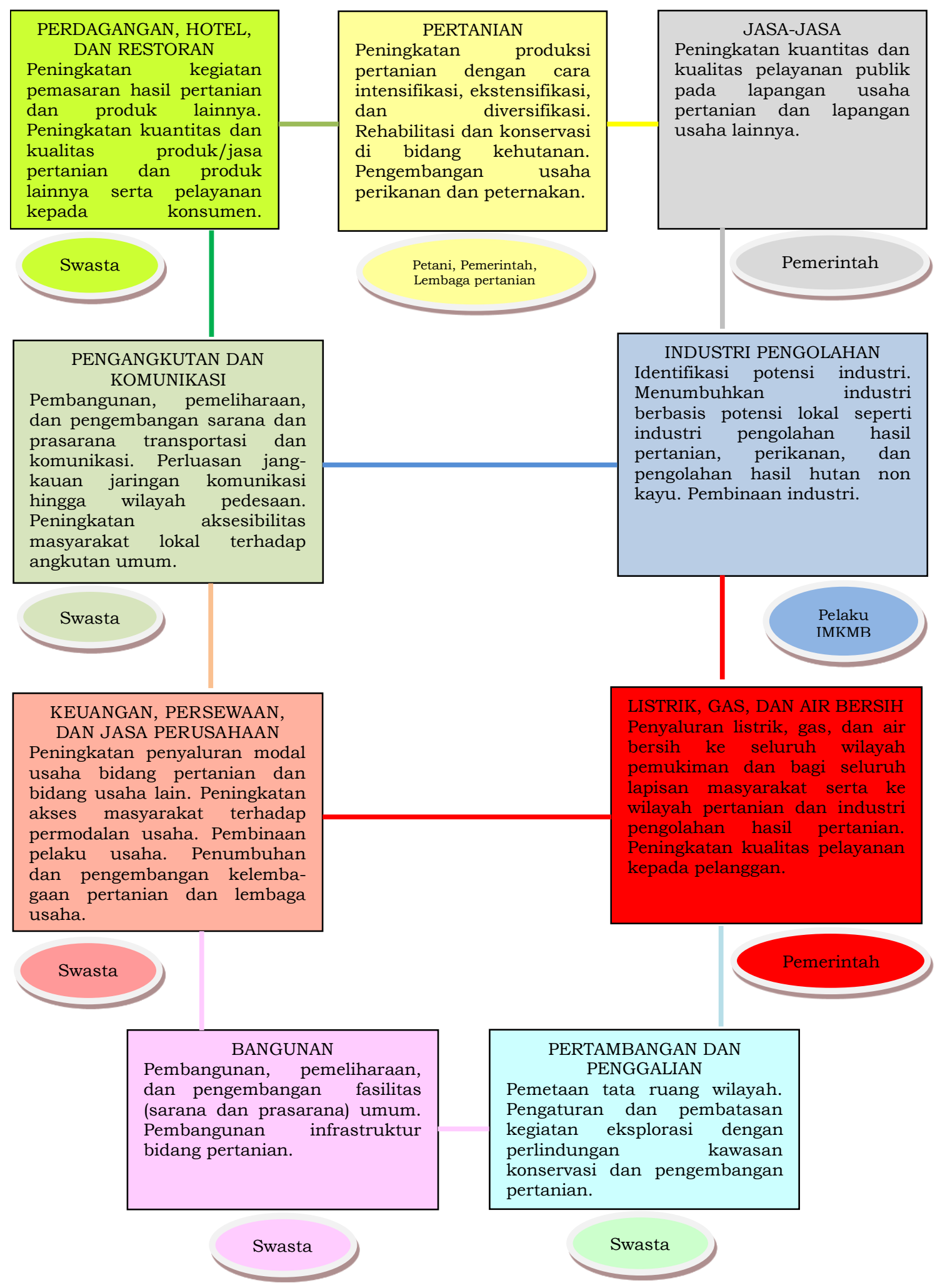

Gambar 3. Model Pengembangan Pertanian di Kabupaten Mahakam Ulu. 


\section{KESIMPULAN}

Kabupaten Mahakam Ulu memiliki potensi ekonomi pada berbagai lapangan usaha. Potensi ekonomi pada tingkat lokal memiliki peluang untuk terus dikembangkan. Sekitar $73 \%$ potensi sumberdaya alam, sumberdaya manusia, dan sumberdaya fisik mendukung pengembangan kegiatan ekonomi pada tingkat lokal di Kabupaten Mahakam Ulu, namun terdapat sekitar $27 \%$ potensi sumberdaya yang perlu dikelola secara lebih intensif. Model pengembangan pertanian menunjukkan pembangunan pertanian dipengaruhi dan perlu didukung oleh pembangunan pada lapangan usaha lainnya.

\section{DAFTAR PUSTAKA}

Badan Pusat Statistik Kabupaten Mahakam Ulu (BPS Mahulu). (2018). Mahakam Ulu dalam Angka 2018. Sendawar: BPS Mahulu.

Balai Pustaka. (2005). Kamus Besar Bahasa Indonesia. Jakarta: Balai Pustaka.

$\begin{array}{lr}\text { Karmini. (2014a). } & \text { UPAYA } \\ \text { PENINGKATAN } & \text { LAJU } \\ \text { PERTUMBUHAN } & \text { PRODUK } \\ \text { DOMESTIK } & \text { REGIONAL } \\ \text { BRUTO DARI } & \text { SEKTOR } \\ \text { PERTANIAN, PETERNAKAN, } & \text { PEHUTANAN, } \\ \text { KEHUN } \\ \text { PERIKANAN. LEMBUSUANA, } \\ \text { 14(160), 23-26. }\end{array}$

Karmini. (2014b). ANALISIS

INVESTASI PADA KEGIATAN

PERTANIAN TANAMAN

PANGAN DAN

HORTIKULTURA DI

KABUPATEN KUTAI

KARTANEGARA. RISET

KALTIM, 2(4), 13-27.

Karmini. (2015). BEBERAPA POTENSI KEGIATAN
EKONOMI YANG

BERKEMBANG DI

KABUPATEN KUTAI

KARTANEGARA. GERBANG

BALITBANGDAKU, 5(23), 77-

81.

Karmini. (2016a). KETERSEDIAAN SUMBERDAYA DAN PRODUKSI HASIL HUTAN, PETERNAKAN, DAN PERIKANAN DI KABUPATEN KUTAI KARTANEGARA. AGRIFOR, 15(2), 211-222.

Karmini. (2016b). METODE PERHITUNGAN PRODUK DOMESTIK REGIONAL BRUTO SEKTOR PENGANGKUTAN DAN KOMUNIKASI DAN SEKTOR JASA-JASA. LEMBUSUANA, 16(185), 15-24.

Karmini. (2016c). KALKULASI PRODUK DOMESTIK REGIONAL BRUTO SEKTOR KEUANGAN, PERSEWAAN, DAN JASA PERUSAHAAN. GERBANG ETAM, 10(2), 54-60.

Karmini. (2016d). FAKTOR-FAKTOR PENENTU DAYA TARIK INVESTASI NON TAMBANG DI KABUPATEN KUTAI KARTANEGARA. RISET KALTIM, 4(1), 29-36.

Karmini. (2019). STRATEGI PENINGKATAN INVESTASI NON TAMBANG DI KABUPATEN KUTAI KARTANEGARA. RISET PEMBANGUNAN, 1(2), 71-78.

Karmini (2021). MODEL PENGEMBANGAN POTENSI EKONOMI LOKAL DI WILAYAH PEMBANGUNAN DATARAN RENDAH KABUPATEN KUTAI BARAT. PROSIDING SEMINAR NASIONAL PERTANIAN UNIVERSITAS MULAWARMAN 
2021, 1-10.

Mellor, J.W., Agricultural Development and Economic Transformation. Promoting Growth with Poverty Reduction. Switzerland: Palgrave Macmillan.

Northon, G.W., Alwang, J., Masters, W.A. (2010). Economics of Agricultural Development. New York: Routledge.

Purnomo, A.H. (2014). STRATEGI PENGEMBANGAN

PERTANIAN KALIMANTAN TIMUR. RISET KALTIM, 2(4), 112.
Sitanala, F., Sukanta, J., Samsuri, A., Kurniawan, Witarsa, P.M. (1988). Materi Pokok Ekonomi Sumber Daya. Jakarta: Karunika. 